\title{
Determination of Glutathione in Austrian Wine Samples: The Effects of Freezing, the Choice of Yeast and Storage
}

\author{
Danka Dragojlović ${ }^{*}$, Christian Philipp², Karin Korntheuer², Christian Bader², \\ Elsa Patzl-Fischerleitner², Karin Mandl², Reinhard Eder² \\ ${ }^{1}$ Institute of Food Technology, University of Novi Sad, 21000 Novi Sad, Bulevar cara Lazara 1, Serbia \\ 2 Department of Chemistry and Quality Control, Federal College and Research Institute for Viticulture and Pomology, \\ Klosterneuburg - HBLA, 3400 Klosterneuburg, Wiener Strasse 74, Austria \\ * Corresponding author, e-mail: danka.dragojlovic@fins.uns.ac.rs
}

Received: 11 January 2019, Accepted: 02 May 2019, Published online: 02 July 2019

\begin{abstract}
Glutathione (GSH, y-L-Glutamyl-L-Cysteinyl Glycine) is a tripeptide of L-glutamate, L-cysteine and glycine. GSH in wine is derived from either grapes or yeast, during alcoholic fermentation. The GSH concentration in wine is very variable and depends on the environmental conditions as well as viticultural practices. During winemaking GSH has a significant role in oxidation prevention due to its unique redox and nucleophilic properties. Since GSH is very reactive it is highly important to prepare samples immediately and under inert conditions just prior to the determination of the GSH concentration. Therefore the aim of this research was to implement a method for the quantitative determination of GSH levels in grape juices (musts) made from different Austrian grape varieties and to investigate the influence of yeast on the GSH content in wine after aging. The results of this research have shown that monitoring with nitrogen gas, sulphur dioxide and freezing process at $-25^{\circ} \mathrm{C}$ led to a good protective effect on the free glutathione amount in wine and grape samples. The GSH concentration in the samples was variable. Levels were ranging from non-detectable to up to $23.10 \mathrm{mg} / \mathrm{l}$, and it showed that grape variety has no impact on GSH concentration in the must. Furthermore the results suggest that the choice of yeast has an impact on GSH content in wine even after 6 and 18 months of aging.
\end{abstract}

Keywords

glutathione, Austrian grape varieties, HPLC, freezing effect, yeast

\section{Introduction}

Glutathione (GSH) is a tripeptide of L-glutamate, L-cysteine and glycine. GSH is found in two forms in the cell: reduced (GSH) and oxidized as glutathione disulphide (GSSG) [1]. GSSG is formed during oxidation of GSH, and it can be reduced back to GSH by glutathione reductase [2].

In wine, GSH is derived either from grapes where it fulfills an important role in plant cells in terms of the antioxidant system, sulphur metabolism and the detoxification of xenobiotics or from yeast during fermentation [3]. It is found that, depending on stress conditions, yeasts are able to utilize and secret GSH during alcoholic fermentation, and in addition GSH is the main sulphur compound in the yeast's cell [4-6]. Therefore the GSH concentration in wine is highly variable and depends on the environmental conditions and viticultural practices [7]. In must and wine GSH reacts with oxidized phenolic compounds, such as caftaric acid quinones or other oxidation products $[8,9]$.
This reaction leads toward the formation of the grape reaction product (GRP). These reactions occur firstly during grape crushing, when phenolic compounds are oxidized by grape polyphenol oxidases but may also occur later in wine when chemical oxidation occurs $[8,10]$.

GSH has a possible protective function against oxidation. A simple mechanism of protection is based on a reaction in which the reduced glutathione form (GSH) is oxidized to glutathione disulfide (GSSG), thereby releasing protons and electrons used in coupled reactions to preserve molecules against oxidation [11]. Additionally, the level and redox status of GSH in plant can estimate the rate of oxidative stress and eco-toxicological injury [12].

Sulphur dioxide $\left(\mathrm{SO}_{2}\right)$ is the most widely used preservative in winemaking, displaying antioxidant, antimicrobial and anti-enzymatic properties [13, 14]. However, health-related concerns have resulted in consumer pressure to 
reduce its use [15]. Using other alternative antioxidants, such as GSH might be able to permit a lower $\mathrm{SO}_{2}$ dosage in wine. Furthermore, GSH concentration higher than a few milligrams per liter in wine can effectively protect the varietal thiol and aroma compounds such as esters and terpenes, by acting as a competitor for quinone reduction due to its free sulfhydryl (SH) moiety [16]. Similarly, GSH is able to prevent the formation of atypical ageing characters, such as 2-aminoacetophenone [16].

Nevertheless the supplementation of purified glutathione in maximum $20 \mathrm{mg} / \mathrm{l}$ in must and wine is allowed in two resolutions of OIV $[17,18]$. On one side the use of purified glutathione is forbidden from the European legislation of the European Union, but on the other side it is allowed to add GSH-enriched inactive yeast preparations [6, 10, 19].

Since GSH is a very reactive tripeptide, there are many difficulties for its determination. As GSH concentration decreases, it is of high importance to immediately prepare the samples [20]. There are not many publications regarding the freezing process on GSH concentration in must. Additionally GSH is well known for its benefits against the formation of atypical aging substances. Therefore, the aim of this research was to observe the GSH content in frozen samples of Austrian grape musts and to investigate the yeast influence on GSH content in wines, fermented with different yeasts, after 6 and 18 months of aging.

\section{Material and methods}

\subsection{Samples}

This study was taken within two different experiments. To investigate the influence of freezing process on GSH the prestudy was obtained, which included analyzes of 22 fresh and frozen must samples from different vineyards in Austria: Müller Thurgau from 1 vineyard, Sankt Laurent from 1 vineyard, Chardonnay from 8 different vineyards, Zweigelt from 2 different vineyards, Grüner Veltliner from 2 different vineyards, Welschriesling from 3 different vineyards, Blaufränkisch from 1 vineyard, Blauburger from 1 vineyard, Traminer from 1 vineyard, Sauvignon blanc from 1 vineyard, Weissburgunder from 1 vineyard. Subsequently, 51 different must samples were analyzed, from different Austrian vineyard regions. Immediately after crushing the grapes, $50 \mathrm{mg} \mathrm{SO}_{2} / 1$ was added to all fresh musts to inhibit GSH oxidation. Samples were frozen under $-25^{\circ} \mathrm{C}$ for three days, and then analyzed. All samples were analyzed in triplicate.

The second experiment was monitoring the GSH concentration in two different wines which were fermented with different yeasts. The composition of grape juices (musts) is shown in Table 1. The fermentations were carried out in the cellar department in two grape varieties (Welschriesling and Grüner Veltliner). The fermentations of the commercial yeast were conducted in 341 glass bottles by both varieties. Active dry yeasts (as listed below in Table 2) were rehydrated according to the instructions of the different yeast producers. In addition, $15 \mathrm{~g} / 341$ yeast nutrition Fermoplus Integrateur (AEB Group, Brescia, Italy) was added. The fermentation temperature was $22{ }^{\circ} \mathrm{C}$ in the cellar and fermentation was controlled by analyzing with OenoFossTM (Foss, Hamburg Germany). Fermentations were carried out in triplicate. After the bottling the measurements of reduced glutathione in the variety Grüner Veltliner were done after 18 months and in the variety Welschriesling after 6 months. The bottled wines were stored at $15{ }^{\circ} \mathrm{C}$ under the same conditions until they were analyzed. All samples were taken in duplicate from one bottle of each replicate.

\subsection{Chemicals and reagents}

Deionized water was used, HPLC-grade reagents and solvents were used for the mobile phases. For the mobile phase a preparation of $50 \mathrm{mM}$ sodium acetate (Merck, Germany), pH 5.7 (buffer "A") and methanol (buffer "B") were used. Derivatizing reagents were prepared as followed: 2 mg o-phthalaldehyde (OPA) (Merck, Germany) dissolved in $1 \mathrm{ml}$ methanol (Merck, Germany), $2 \mu \mathrm{l}$ of 2-aminoethanol dissolved in $1 \mathrm{ml}$ of $0.8 \mathrm{M}$ sodium borate (pH 7.4) (Merck, Germany). Furthermore for the stock standard solutions included reduced glutathione, $98 \%$ purity (105 mg/l) and L-cysteine (Merck, Germany) $(209 \mathrm{mg} / \mathrm{l})$, which was prepared in $5 \mathrm{mM}$ sodium acetate buffer containing $0.1 \mathrm{mM}$ EDTA.

\subsection{Samples preparation}

Each sample was centrifuged for $5 \mathrm{~min}, 7500 \mathrm{rpm}$ (Micro centrifuge, Thermo-Fisher-Scientific, USA), and filtrated through $0.45 \mu \mathrm{m}$ syringe filter. For analysis $0.75 \mathrm{ml}$ of sample was taken.

Table 1 Composition of the Grüner Veltliner and Welschriesling grape musts

\begin{tabular}{lccccc}
\hline Grape must & ${ }^{\circ} \mathrm{KMW}^{\dagger}$ & $\mathrm{pH}$ & $\begin{array}{c}\mathrm{YAN}^{\ddagger} \\
(\mathrm{mg} / \mathrm{l})\end{array}$ & $\begin{array}{c}\mathrm{NH}_{4}^{+} \\
(\mathrm{mg} / \mathrm{l})\end{array}$ & $\begin{array}{c}\mathrm{Total} \mathrm{acid}^{\S} \\
(\mathrm{g} / \mathrm{l})^{\dagger}\end{array}$ \\
\hline $\begin{array}{l}\text { Grüner } \\
\text { Veltliner }\end{array}$ & 18.5 & 3.3 & 125 & 87 & 4.8 \\
\begin{tabular}{l} 
Welschriesling \\
\hline
\end{tabular} & 16.3 & 3.3 & 281 & 195 & 7.8 \\
\hline
\end{tabular}

$\uparrow 1^{\circ} \mathrm{KMW}\left(\right.$ Klosterneuburger Mostwaage) $=4.86^{\circ}$ Oe $\ddagger$ YAN $=$ Yeast Assimilable Nitrogen $\S$ Total acid is expressed as tartaric acid $\mathrm{g} / 1$ 
Table 2 List of yeasts used

\begin{tabular}{l}
\hline List of yeasts used for Welschriesling grape variety \\
\hline SP39 (SP39 Station Oenotechnique de Champagne, SAS Sofralab, \\
Epernay Cedex, France) \\
SP Organic (SP Organic Station Oenotechnique de Champagne, \\
SAS Sofralab, Epernay Cedex, France) \\
SO. Delight (SO. Delight, Martin Vialatte, SAS Sofralab, \\
Epernay Cedex, France) \\
La Persane (La Persane Oenofrance SAS Sofralab, Epernay Cedex, \\
France) \\
Zymaflore X16 (Zymaflore ${ }^{\text {X } 16, L a f f o r t, ~ B o r d e a u x ~ C e d e x, ~ F r a n c e) ~}$
\end{tabular}

Zymaflore X5 (Zymaflore ${ }^{\circledR}$ X5 ,Laffort Bordeaux Cedex, France)

Actiflore RMS 2 (Actiflore ${ }^{\circledR}$ RMS 2, Laffort Bordeaux Cedex, France)

Oenoferm Freddo (Oenoferm ${ }^{\circledR}$ Freddo, Erbslöh Geisenheim AG, Geisenheim, Germany)

Oenoferm Riesling (Oenoferm ${ }^{\circledR}$ Riesling, Erbslöh Geisenheim AG, Geisenheim, Germany)

Oenoferm X-treme ( Oenoferm ${ }^{\circledR}$ X-treme, Erbslöh Geisenheim AG, Geisenheim, Germany)

Oenoferm Klbg (Oenoferm ${ }^{\circledR}$ Klosterneuburg, Erbslöh Geisenheim AG, Geisenheim, Germany)

PREZISO Universal (PREZISO Hefe Universal, RWA Raiffeisen Ware Austria Aktiengesellschaft, Vienna, Austria)

PREZISO Primeur (PREZISO Weissweinhefe Primeur, RWA Raiffeisen Ware Austria Aktiengesellschaft, Vienna, Austria)

PREZISO Weiß \& Fruchtig (PREZISO Weißweinhefe Weiß \& Fruchtig, RWA Raiffeisen Ware Austria Aktiengesellschaft, Vienna, Austria)

IOC 182007 (IOC 18-2007, Erbslöh Geisenheim AG, Geisenheim, Germany)

Lalvin QA 23 (Lalvin QA 23, Lallemand Specialties GmbH, Vienna, Austria)

Uvaferm CEG (Uvaferm CEG, Lallemand Specialties GmbH, Vienna, Austria)

Fermicru LVCB ( Fermicru ${ }^{\circledR}$ LVCB, DSM Food Specialties B.V. and DSM Nutritional Products AG,AX Delft, Netherlands)

Fermicru VB1( Fermicru® VB1, DSM Food Specialties B.V. and DSM Nutritional Products AG,AX Delft, Netherlands),

Fermcru LS2 (Fermicru ${ }^{\circledR}$ LS2, DSM Food Specialties B.V. and DSM Nutritional Products AG, AX Delft, Netherlands)

Fermicru AR2 (Fermicruß Ar2, DSM Food Specialties B.V. and DSM Nutritional Products AG, AX Delft Netherlands)
List of yeasts used for Grüner Veltliner grape variety

Oenoferm Bio (Oenoferm ${ }^{\circledR}$ Bio Selection Klingelberg, Erbslöh

Geisenheim AG, Geisenheim, Germany)

Oenoferm PinoType (Oenoferm ${ }^{\circledR}$ PinotType, Erbslöh Geisenheim AG, Geisenheim, Germany)

Oenoferm Veltliner (Oenoferm ${ }^{\circledR}$ Veltliner, Erbslöh Geisenheim AG, Geisenheim, Germany)

PREZISO Weiß\&Fruchtig (PREZISO Weißweinhefe Weiß \& Fruchtig, RWA Raiffeisen Ware Austria Aktiengesellschaft, Vienna, Austria)

PREZISO Universal (PREZISO Hefe Universal, RWA Raiffeisen Ware Austria Aktiengesellschaft, Vienna, Austria)

PREZISO Weiss\&Komplex (PREZISO Weissweinhefe Weiss \& Komplex, RWA Raiffeisen Ware Austria Aktiengesellschaft, Vienna, Austria),

LittoLevure Elégance (LittoLevure Elégance, Erbslöh Geisenheim AG, Geisenheim, Germany)

Fermol Associées (Fermol®Associées, AEB Group, Brescia, Italy)

Fermol Iper R(Fermol® Iper R, AEB Group, Brescia, Italy)

Fermol Bayanus Lipari (Fermol@Bayanus Lipari, AEB Group, Brescia, Italy)

IOC B 3000 (IOC B3000, Lallemand Specialties GmbH, Vienna, Austria)

IOC Revelation Thiols (IOC Revelation Thiols, Lallemand Specialties $\mathrm{GmbH}$, Vienna, Austria),

IOC 18 -2007 ( IOC18 -2007, Erbslöh Geisenheim AG, Geisenheim, Germany),

Filtraferm C Fresh (Filtraferm C Fresh, Lallemand Specialties GmbH, Vienna, Austria)

SIHA White Arome (SIHA®White Arome, EATON, Nettersheim, Germany)

Sihaferm Element (SIHAFERM®Element, EATON, Nettersheim, Germany),

SIHA Cryarome (SIHA Cryarome ${ }^{\circledR}$, EATON, Nettersheim, Germany),

SIHA Aktivhefe 7 (SIHA®Aktivhefe 7, EATON, Nettersheim, Germany)

Uvaferm WAM (Uvaferm WAM, Lallemand Specialties GmbH, Vienna, Austria)

Fermicru VB1( Fermicru® VB1, DSM Food Specialties B.V. and DSM Nutritional Products AG,AX Delft, Netherlands)

Fermicru AR2 (Fermicru® Ar2, DSM Food Specialties B.V. and DSM Nutritional Products AG, AX Delft, Netherlands),

Fermicru LVCB ( Fermicru ${ }^{\circledR}$ LVCB, DSM Food Specialties B.V. and DSM Nutritional Products AG,AX Delft, Netherlands),

Zymaflore X5 (Zymaflore $®$ X5 ,Laffort Bordeaux Cedex, France)

Zymaflore Alpha (Zymaflore ${ }^{\circledR} A l p h a$ TD.sacch. Laffort Bordeaux Cedex, France)

Zymaflore VL 3 (Zymaflore ${ }^{\circledR V L} 3$, Laffort Bordeaux Cedex, France).
The sample was then diluted with $0.75 \mathrm{ml}$ of $5 \mathrm{mM}$ sodium acetate buffer ( $\mathrm{pH} 4$ ) containing $0.1 \mathrm{mM}$ EDTA. All reagents and samples were put into sample vials
$(1.5 \mathrm{ml})$ which had been previously purged with nitrogen gas, shortly before sampling. The headspace was also purged with nitrogen gas before sealing the vial 
with a Teflon-faced septum. In order to investigate the stability of prepared samples, the prestudy was conducted. Samples were prepared with and without addition of $\mathrm{SO}_{2}$ and nitrogen purging. Additionally, samples were analyzed after 2, 6, 20 and 48 hours at room temperature, which corresponds to autosampler temperature. Without the addition of $\mathrm{SO}_{2}$ and nitrogen purging, it was not found any measurable GSH in samples. However, as it is shown in the Fig. 1, after 20 hours of sample's storage, the GSH content intends to decrease. Therefore all prepared samples were in autosampler never longer than 8 hours.

\subsection{Instrumentation}

An Agilent 1220 Series HPLC was used for quantification. GSH was detected on an Agilent 1100 fluorescence detector: wavelengths excitation $340 \mathrm{~nm}$ and emission $450 \mathrm{~nm}$. The gradient program used for the mobile phases is shown in Table 3. Derivatives were separated on a column (Nucleoshell RP 18, $2.7 \mu \mathrm{m}, 150 \mathrm{~mm} \times 2 \mathrm{~mm}$ ). The online pre-column derivatization with o-phthalaldehyde and 2-aminoethanol (OPA) is a modification of a manual analysis described by Mopper and Delmas [21]. The online derivatization procedure was as follows: $2 \mu \mathrm{l}$ of OPA was withdrawn from the vial and the needle was afterward washed with $\mathrm{H}_{2} \mathrm{O} .5 \mu \mathrm{l}$ of sample was withdrawn from the sample vial and the needle was washed again with $\mathrm{H}_{2} \mathrm{O}$. Finally, $2 \mu 1$ of 2 -aminoethanol was withdrawn and mixed

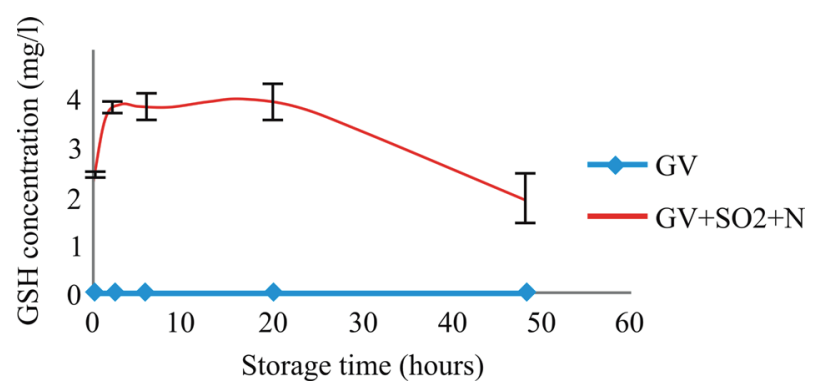

Fig. 1 Influence of storage time of samples on GSH content, at room temperature. Results are shown as mean value $(n=3) \pm$ standard deviation. GV presents Grüner Veltliner grape juice without addition of $\mathrm{SO}_{2}$ and nitrogen purging, $\mathrm{GV}+\mathrm{SO}_{2}+\mathrm{N}$ presents Grüner Veltliner grape juice with addition of $\mathrm{SO}_{2}$ and nitrogen purging

Table 3 Elution Gradient

\begin{tabular}{lcc}
\hline Time $(\mathrm{min})$ & Buffer A $(\%)^{*}$ & Buffer B $(\%)^{* *}$ \\
\hline 1 & 80 & 20 \\
10 & 60 & 40 \\
15 & 60 & 40 \\
17 & 80 & 20 \\
\hline
\end{tabular}

*Sodium acetate **Methanol for exactly 1 minute by moving the reagents and sample volumes back and forth inside the auto-sampler's syringe capillary. The derivatized sample was injected immediately by automatic injector for analysis. For each sample this automatic derivatization procedure was performed just before injection.

\subsection{Statistical analyses}

Firstly, the data set was tested for normal distribution using an exploratory data analysis. No outliers were eliminated. In the case of a normal distribution, the mean values of the independent samples were compared using a one-factorial analysis of variance and tested for variance homogeneity. If variance homogeneity was proved, an evaluation was done using the Tukey B test at the significance level of 0.05 . If there was no variance homogeneity, the Tunnet-T3 test was also used at the significance level of 0.05. If the respective data set was not distributed normally, a Kruskal-Wallis test was conducted at the significance level of 0.05 and evaluated in the form of pairwise comparisons. The data were statistically analyzed using the Statistica software version 13 (Statsoft Inc., 2013, USA) and SPSS 22.0 (IBM, 2013, USA).

\section{Results and discussion}

A five-point calibration curve was linear in the range of 0.1 to $26.25 \mathrm{mg} / \mathrm{l}$. Limit of detection (LOD) was $0.15 \mathrm{mg} / 1$ and limit of quantification (LOQ) was $0.5 \mathrm{mg} / 1$. In this research glutathione was observed only in the reduced form (GSH). Working area was between 0.1-26.25 mg/1. The retention time of GSH was 4.4 min based on standards.

Results from the study are presented in Table 4, where the differences in GSH content are shown between the fresh samples and in the same samples after three days of freezing at $-25^{\circ} \mathrm{C}$. There was a significant statistical difference in most of the samples, thus to handle the same conditions of sample preparation, all samples were frozen, exactly for three days.

\subsection{Determination of GSH in different must}

The GSH content in must was variable. Levels were ranging from non-detectable to $23.10 \mathrm{mg} / \mathrm{l}$. The results are shown in Table 5. Several factors can influence the GSH concentration in musts, for example tyrosinase activity, environmental conditions and exposure to oxygen [22-24]. A correlation has also been found with the amount of readily assimilable nitrogen in the soil [16]. According to the results of this study, the reduced glutathione amount is not 
Table 4 GSH content (mg/1) in fresh and frozen samples

\begin{tabular}{lcc}
\hline Grape Variety & Fresh samples & Frozen samples \\
\hline Müller Thurgau1 & $\mathbf{2 0 . 5 7} \pm \mathbf{0 . 0 9}^{\mathrm{a}}$ & $\mathbf{2 3 . 0 9} \pm \mathbf{0 . 0 2}^{\mathrm{b}}$ \\
Sankt Laurent & $\mathbf{8 . 6 5} \pm \mathbf{0 . 0 7}^{\mathrm{a}}$ & $\mathbf{9 . 0 5} \pm \mathbf{0 . 0 7}^{\mathrm{b}}$ \\
Chardonnay1 & $5.455 \pm 0.08^{\mathrm{a}}$ & $5.70 \pm 0.03^{\mathrm{a}}$ \\
Chardonnay2 & $13.13 \pm 0.09^{\mathrm{a}}$ & $13.89 \pm 0.43^{\mathrm{a}}$ \\
Chardonnay3 & $\mathbf{2 3 . 0 6} \pm \mathbf{0 . 0 5}^{\mathrm{a}}$ & $\mathbf{2 1 . 7 0} \pm \mathbf{0 . 1 1}^{\mathrm{b}}$ \\
Chardonnay4 & $14.56 \pm 0.09^{\mathrm{a}}$ & $14.40 \pm 0.14^{\mathrm{a}}$ \\
Chardonnay5 & $\mathbf{9 . 3 5} \pm \mathbf{0 . 0 7}^{\mathrm{a}}$ & $\mathbf{5 . 8 7} \pm \mathbf{0 . 0 7}^{\mathrm{b}}$ \\
Chardonnay6 & $\mathbf{2 0 . 0 6} \pm \mathbf{0 . 0 6}^{\mathrm{a}}$ & $\mathbf{1 5 . 5 1} \pm \mathbf{0 . 1 3}^{\mathrm{b}}$ \\
Chardonnay7 & $13.60 \pm 0.14^{\mathrm{a}}$ & $14.76 \pm 1.05^{\mathrm{a}}$ \\
Chardonnay8 & $11.62 \pm 0.03^{\mathrm{a}}$ & $11.56 \pm 0.09^{\mathrm{a}}$ \\
Zweigelt1 & $\mathbf{1 5 . 5 1} \pm \mathbf{0 . 2 5}^{\mathrm{a}}$ & $\mathbf{1 3 . 9 0} \pm \mathbf{0 . 0 3}^{\mathrm{b}}$ \\
Zweigelt2 & $\mathbf{9 . 4} \pm \mathbf{0 . 1 4}^{\mathrm{a}}$ & $\mathbf{6 . 1 8} \pm \mathbf{0 . 0 4}$ \\
Grüner Veltliner1 & $\mathbf{3 . 1 9} \pm \mathbf{0 . 1 3}^{\mathrm{a}}$ & $\mathbf{0 . 6 0} \pm \mathbf{0 . 1 4}^{\mathrm{b}}$ \\
Grüner Veltliner2 & $\mathbf{9 . 9 1} \pm \mathbf{0 . 1 5}^{\mathrm{a}}$ & $\mathbf{1 1 . 1 5} \pm \mathbf{0 . 0 8}^{\mathrm{b}}$ \\
Welschriesling1 & $17.92 \pm 0.17^{\mathrm{a}}$ & $17.41 \pm 0.13^{\mathrm{a}}$ \\
Welschriesling2 & $\mathbf{2 8 . 0 1} \pm \mathbf{0 . 1 3}^{\mathrm{a}}$ & $\mathbf{2 1 . 2 6} \pm \mathbf{0 . 0 9}^{\mathrm{b}}$ \\
Welschriesling3 & $\mathbf{9 . 5 5} \pm \mathbf{0 . 0 7}^{\mathrm{a}}$ & $\mathbf{1 1 . 8 0} \pm \mathbf{0 . 2 9}^{\mathrm{b}}$ \\
Blaufränkisch1 & $10.58 \pm 0.11^{\mathrm{a}}$ & $10.39 \pm 0.09^{\mathrm{a}}$ \\
Blauburger1 & $\mathbf{2 0 . 0 5} \pm \mathbf{0 . 0 8}^{\mathrm{a}}$ & $\mathbf{1 7 . 0 5} \pm \mathbf{0 . 2 1}^{\mathrm{b}}$ \\
Traminer1 & $\mathbf{9 . 4 7 5} \pm \mathbf{0 . 1 1}^{\mathrm{a}}$ & $\mathbf{8 . 0 7} \pm \mathbf{0 . 0 5}^{\mathrm{b}}$ \\
Sauvignon Blanc1 & $14.30 \pm 0.14^{\mathrm{a}}$ & $14.52 \pm 0.11^{\mathrm{a}}$ \\
Weissburgunder1 & $\mathbf{7 . 1 5} \pm \mathbf{0 . 0 7}^{\mathrm{a}}$ & $\mathbf{8 . 4 0} \pm \mathbf{0 . 1 4}^{\mathrm{b}}$ \\
\hline
\end{tabular}

Results are shown as mean value $(n=3) \pm$ standard deviation

*a, $b$ indicates significant difference between value

in correlation with the grape variety. It was discovered that one grape variety contained different glutathione amount. However this is only an assumption and this research demands further investigations.

\subsection{Monitoring GSH content in wines fermented with different yeast}

21 commercial yeast strains for the grape variety Welschriesling and 25 yeast strains for the variety Grüner Veltliner were used to investigate the influence of the yeast strain on the content of GSH in finished wine. As shown in Fig. 2, concerning the variety Welschriesling after 6 months of aging in the bottle, the content of GSH ranged between 2 and $5 \mathrm{mg} / \mathrm{L}$. These results are in agreement with $[6,25,26]$.

The use of different yeasts showed different amounts of GSH in this experiment. Regarding the strain Uvaferm CEG with less GSH and the strains Preziso Weiß \& Fruchtig and Fermicru LVCB with higher amount of GSH, statistical differences were found. In common literature it is well described that there is an impact of the yeast strain

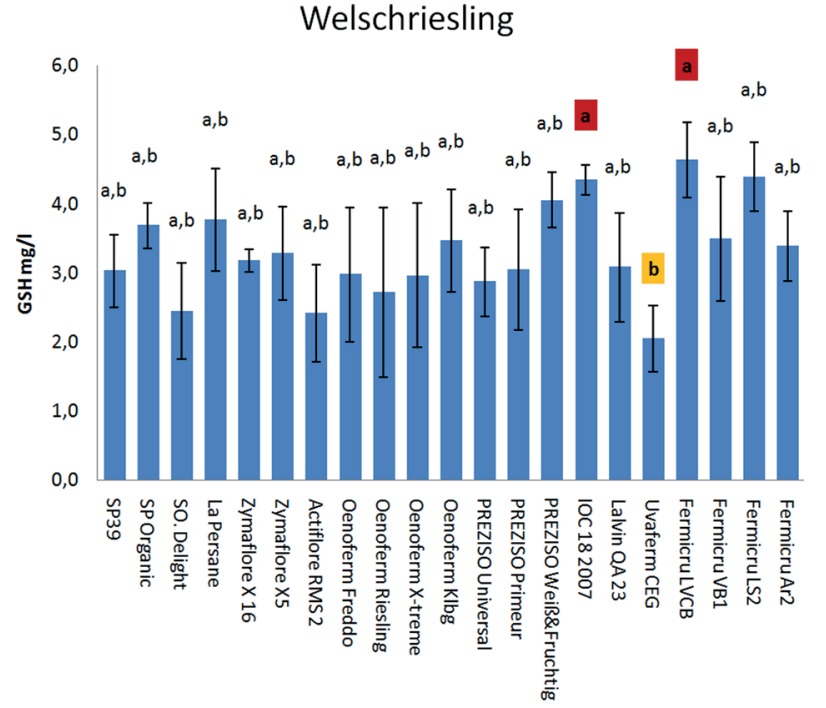

Fig. 2 Average amounts of GSH, variety Welschriesling, vinified with 21 different commercial yeasts, after 6 months aging in the bottle.

Results are shown as mean value $(n=6) \pm$ standard deviation

$*_{\mathrm{a}}$, b indicates significant difference between value.

on the final GSH concentration in finished wine $[5,6]$. The GSH concentration in Grüner Veltliner wines is shown in Fig. 3. Musts that were fermented with different yeast strains, measured after 18 months of aging, ranged between 0.3 and $1 \mathrm{mg} / \mathrm{L}$. These low concentrations could be explained by the fact that within $\mathrm{pH}$ conditions of 3.3 in wine, the autoxidation of GSH is possible and the presence of ortho-quinones leads to the formation of GRP and similar products and hence decreasing the concentration of GSH over the time [19, 27]. Nevertheless there was a statistical difference between the yeast strain Zymaflore VL3

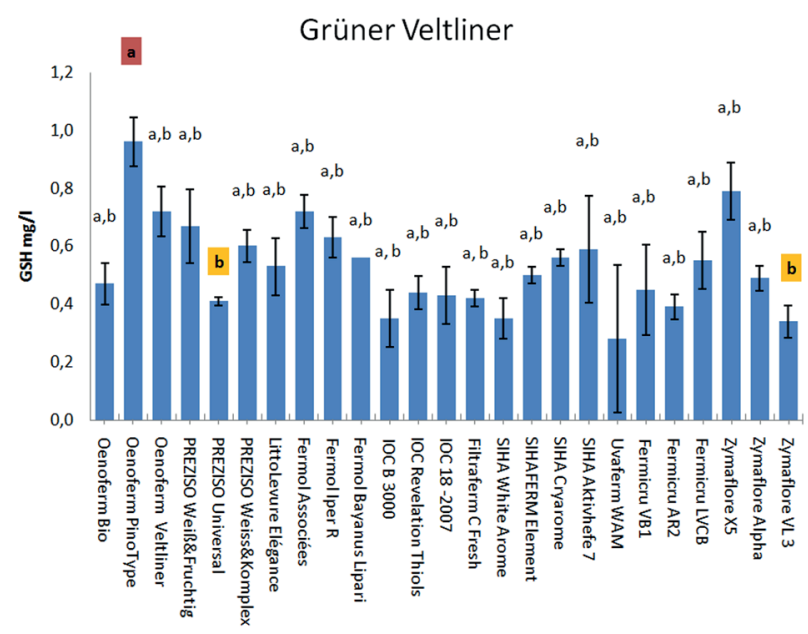

Fig. 3 Average amounts of GSH, variety Grüner Veltliner, vinified with 25 different commercial yeasts, after 18 months aging in the bottle.

Results are shown as mean value $(n=6) \pm$ standard deviation

*a, b indicates significant difference between value 
Table 5 GSH concentrations in different Austrian grape varieties

\begin{tabular}{|c|c|c|c|}
\hline Grape variety & Glutathione $(\mathrm{mg} / \mathrm{l})$ & Grape variety & Glutathione $(\mathrm{mg} / \mathrm{l})$ \\
\hline Müller Thurgau2 & $23.10 \pm 0.05$ & Grüner Veltliner9 & $4.41 \pm 0.18$ \\
\hline Chardonnay9 & $5.35 \pm 0.46$ & Grüner Veltliner10 & $0.36 \pm 0.25$ \\
\hline Chardonnay10 & $14.14 \pm 0.78$ & Grüner Veltliner11 & $2.46 \pm 0.35$ \\
\hline Chardonnay11 & $21.82 \pm 0.29$ & Grüner Veltliner12 & $0.28 \pm 0.04$ \\
\hline Chardonnay12 & $14.85 \pm 0.49$ & Grüner Veltliner13 & $2.43 \pm 0.17$ \\
\hline Chardonnay13 & $5.68 \pm 0.33$ & Grüner Veltliner14 & $9.60 \pm 0.71$ \\
\hline Chardonnay14 & $15.66 \pm 0.09$ & Grüner Veltliner15 & $1.32 \pm 0.10$ \\
\hline Chardonnay15 & $15.76 \pm 0.37$ & Grüner Veltliner16 & $0.29 \pm 0.06$ \\
\hline Chardonnay16 & $11.75 \pm 0.37$ & Grüner Veltliner17 & nd \\
\hline Chardonnay17 & $5.56 \pm 0.08$ & Welschriesling4 & $17.15 \pm 0.49$ \\
\hline Chardonnay18 & $\mathrm{nd \dagger}$ & Welschriesling5 & $21.64 \pm 0.64$ \\
\hline Chardonnay19 & $0.48 \pm 0.20$ & Welschriesling6 & $11.85 \pm 0.37$ \\
\hline Chardonnay 20 & $0.57 \pm 0.10$ & Welschriesling7 & nd \\
\hline Zweigelt3 & $14.04 \pm 0.23$ & Welschriesling8 & $0.59 \pm 0.23$ \\
\hline Zweigelt4 & $6.19 \pm 0.04$ & Blaufränkisch2 & $10.49 \pm 0.04$ \\
\hline Zweigelt5 & nd & Blaufränkisch3 & $0.37 \pm 0.11$ \\
\hline Zweigelt6 & $4.4 \pm 0.07$ & Blaufränkisch 4 & $1.46 \pm 0.11$ \\
\hline Zweigelt7 & nd & Blauburger2 & $17.10 \pm 0.28$ \\
\hline Zweigelt8 & nd & Traminer2 & $7.81 \pm 0.31$ \\
\hline Zweigelt9 & nd & Sauvignon Blanc2 & $14.05 \pm 0.78$ \\
\hline Grüner Veltliner3 & $0.35 \pm 0.21$ & Sauvignon Blanc3 & $4.03 \pm 0.06$ \\
\hline Grüner Veltliner4 & nd & Weissburgunder2 & $7.92 \pm 0.53$ \\
\hline Grüner Veltliner5 & $11.10 \pm 0.02$ & Gelber Muskateller & nd \\
\hline Grüner Veltliner6 & $0.51 \pm 0.15$ & Rheinriesling1 & $0.48 \pm 0.08$ \\
\hline Grüner Veltliner7 & nd & Rheinriesling2 & $0.42 \pm 0.14$ \\
\hline Grüner Veltliner8 & $0.32 \pm 0.03$ & & \\
\hline
\end{tabular}

Results are shown as mean value $(n=3) \pm$ standard deviation $\uparrow$ nd $=$ non-detectable $(\mathrm{LOD}=0.15 \mathrm{mg} / \mathrm{l})$

and Preziso Universal with lower GSH concentrations and Oenoferm PinoType with higher amounts of GSH even after 18 month of aging in the bottle.

\section{Conclusion}

Glutathione (GSH) is a very reactive tripeptide, therefore inert conditions during sample preparation are required. Monitoring with sulphur dioxide, nitrogen gas, and freezing process at $-25^{\circ} \mathrm{C}$ leads to a good protective effect on the free glutathione amount in wine and grape samples.

\section{References}

[1] Fahey, R. C. "Novel Thiols of Prokaryotes", Annual Review of Microbiology, 55(1), pp. 333-356, 2001. https://doi.org/10.1146/annurev.micro.55.1.333

[2] Carmel-Harel, O., Storz, G. "Roles of the Glutathione- and Thioredoxin-Dependent Reduction Systems in the Escherichia coli and Saccharomyces cerevisiae Responses to Oxidative Stress", Annual Review of Microbiology, 54(1), pp. 439-461, 2000. https://doi.org/10.1146/annurev.micro.54.1.439
The freezing process is suitable for delaying the analysis of samples. Glutathione concentration (GSH) in Austrian grape varieties is very variable, and it is not in correlation with the grape varieties. On the other hand there was an influence of different yeast strains on the content of GSH in finished wine even after 18 months of aging.

\section{Acknowledgement}

This study was performed with the financial support of Association of Austrian Enologist.

[3] Noctor, G., Foyer, C. H. "Ascorbate and Glutathione: Keeping Active Oxygen Under Control", Annual Review of Plant Physiology and Plant Molecular Biology, 49(1), pp. 249-279, 1998. https://doi.org/10.1146/annurev.arplant.49.1.249

[4] Penninckx, M. "A short review on the role of glutathione in the response of yeasts to nutritional, environmental, and oxidative stresses", Enzyme and Microbial Technology, 26(9-10), pp. 737-742, 2000.

https://doi.org/10.1016/S0141-0229(00)00165-4 
[5] Lavigne, V., Pons, A., Dubourdieu, D. "Assay of glutathione in must and wines using capillary electrophoresis and laser-induced fluorescence detection: Changes in concentration in dry white wines during alcoholic fermentation and aging", Journal of Chromatography A, 1139(1), pp. 130-135, 2007.

https://doi.org/10.1016/j.chroma.2006.10.083

[6] Kritzinger, E. C., Bauer, F. F., Du Toit, W. J. "Influence of yeast strain, extended lees contact and nitrogen supplementation on glutathione concentration in wine", Australian Journal of Grape and Wine Research, 19(2), pp. 161-170, 2013.

https://doi.org/10.1111/ajgw.12025

[7] Linsenmeier, A., Loehnertz, O., Bastian, H., Schnug, E. "Influence of increasing sulfur fertilisation on the concentrations of sulfur and glutathione in grapevine cuttings of the varieties Cabernet Sauvignon, Riesling, Sauvignon blanc and Pinot noir", Mitteilungen Klosterneuburg, Rebe und Wein, Obstbau und Früchteverwertung, 63(1), pp. 17-29, 2013.

[8] Sonni, F., Clark, A. C., Prenzler, P. D., Riponi, C., Scollary, G. R. "Antioxidant Action of Glutathione and the Ascorbic Acid / Glutathione Pair in a Model White Wine", Journal of Agricultural and Food Chemistry, 59(8), pp. 3940-3949, 2011.

https://doi.org/10.1021/jf104575w

[9] Sonni, F., Moore, E. G., Clark, A. C., Chinnici, F., Riponi, C., Scollary, G. R. "Impact of Glutathione on the Formation of Methylmethine- and Carboxymethine-Bridged (+)-Catechin Dimers in a Model Wine System", Journal of Agricultural and Food Chemistry, 59(13), pp. 7410-7418, 2011.

https://doi.org/10.1021/jf200968x

[10] Ugliano, M., Kwiatkowski, M., Vidal, S., Capone, D., Siebert, T., Dieval, J.-B., Avagaard, O., Waters, E. J. "Evolution of 3-Mercaptohexanol, Hydrogen Sulfide, and Methyl Mercaptan during Bottle Storage of Sauvignon blanc Wines. Effect of Glutathione, Copper, Oxygen Exposure, and Closure-Derived Oxygen", Journal of Agricultural and Food Chemistry, 59(6), pp. 2564-2572, 2011.

https://doi.org/10.1021/jf1043585

[11] Bade, G. A., Antoce, A. O. "Glutathione as a Possible Replacement of Sulfur Dioxide in Winemaking Technologies: A Review", Scientific Papers B, Horticulture, 59, pp. 123-140, 2015. [online] Available at: https:/pdfs.semanticscholar.org/cbfc/ af1d1c56d622758d601d2fd6c1be4a847741.pdf [Accessed: 10 January 2018]

[12] Hajdinák, P., Czobor, Á., Lőrincz, T., Szarka, A. "The Problem of Glutathione Determination: a Comparative Study on the Measurement of Glutathione from Plant Cells", Periodica Polytechnica Chemical Engineering, 63(1), pp. 1-10, 2019. https://doi.org/10.3311/PPch.11785

[13] Hornsey, I. S. "The Chemistry and Biology of Winemaking", 1st ed., Royal Society of Chemistry, Cambridge, UK, 2007.

[14] Valášek, P., Mlček, J., Fišera, M., Fišerová, L., Sochor, J., Baroň, M., Juríková, T. "Effect of various sulphur dioxide additions on amount of dissolved oxygen, total antioxidant capacity and sensory properties of white wines", Mitteilungen Klosterneuburg, Rebe und Wein, Obstbau und Früchteverwertung, 64(4), pp. 193200, 2014.

[15] Guerrero, R. F., Cantos-Villar, E. "Demonstrating the efficiency of sulphur dioxide replacements in wine: A parameter review",
Trends in Food Science \& Technology, 42(1), pp. 27-43, 2015. https://doi.org/10.1016/j.tifs.2014.11.004

[16] Dubourdieu, D., Lavigne-Cruege, V. "The Role of Glutathione on the Aromatic Evolution of Dry White Wine", Vinidea.net, Wine Internet Technical Journal, 2(2), pp. 1-9, 2004. [online] Available at: https://www.infowine.com/intranet/libretti/libretto993-01-1. pdf [Accessed: 11 November 2017]

[17] International Organization of Vine and Wine "OIV-OENO 445-2015 Treatment of must with glutathione", OIV, Mainz, Germany, 2015.

[18] International Organization of Vine and Wine "OIV-OENO 446-2015 Treatment of wine with glutathione", OIV, Mainz, Germany, 2015.

[19] Kritzinger, E. C., Stander, M. A., Du Toit, W. J. "Assessment of glutathione levels in model solution and grape ferments supplemented with glutathione-enriched inactive dry yeast preparations using a novel UPLC-MS/MS method", Food Additives \& Contaminants: Part A, 30(1), pp. 80-92, 2013.

https://oi.org/10.1080/19440049.2012.728723

[20] Kritzinger, E. C., Bauer, F. F., Du Toit, W. J. "Role of Glutathione in Winemaking: A review", Journal of Agricultural and Food Chemistry, 61(2), pp. 269-277, 2012.

https://doi.org/10.1021/jf303665z

[21] Mopper, K., Delmas, D. "Trace Determination of Biological Thiols by Liquid Chromatography and Precolumn Fluorometric Labeling with o-Phthalaldehyde", Analytical Chemistry, 56(13), pp. 2557-2560, 1984. [online] Available at: https://pubs.acs.org/ doi/pdf/10.1021/ac00277a064 [Accessed: 10 August 2017]

[22] Du Toit, W. J., Lisjak, K., Stander, M., Prevoo, D. "Using LC-MSMS To Assess Glutathione Levels in South African White Grape Juices and Wines Made with Different Levels of Oxygen", Journal of Agricultural and Food Chemistry, 55(8), pp. 2765-2769, 2007.

https://doi.org/10.1021/jf062804p

[23] Maggu, M., Winz, R., Kilmartin, P. A., Trought, M. C. T., Nicolau, L. "Effect of Skin Contact and Pressure on the Composition of Sauvignon Blanc Must", Journal of Agricultural and Food Chemistry, 55(25), pp. 10281-10288, 2007. https://doi.org/10.1021/jf072192o

[24] Patel, P., Herbst-Johnstone, M., Lee, S. A., Gardner, R. C., Weaver, R., Nicolau, L., Kilmartin, P. A. "Influence of Juice Pressing Conditions on Polyphenols, Antioxidants, and Varietal Aroma of Sauvignon blanc Microferments", Journal of Agricultural and Food Chemistry, 58(12), pp. 7280-7288, 2010.

https://doi.org/10.1021/jf100200e

[25] Fracassetti, D., Lawrence, N., Tredoux, A. G. J., Tirelli, A., Nieuwoudt, H. H., Du Toit, W. J. "Quantification of glutathione, catechin and caffeic acid in grape juice and wine by a novel ultra-performance liquid chromatography method", Food Chemistry, 128(4), pp.1136-1142, 2011. https://doi.org/10.1016/j.foodchem.2011.04.001

[26] Marchand, S., de Revel, G. "A HPLC fluorescence-based method for glutathione derivatives quantification in must and wine", Analytica Chimica Acta, 660(1-2), pp. 158-163, 2010. https://doi.org/10.1016/j.aca.2009.09.042

[27] Camera, E., Picardo, M. "Analytical methods to investigate glutathione and related compounds in biological and pathological processes", Journal of Chromatography B, 781(1-2), pp. 181-206, 2002. https://doi.org/10.1016/S1570-0232(02)00618-9 